\title{
ANTROPOLODZY NA WOJNIE
}

\section{MICHAŁ W. KOWALSKI, ANTROPOLODZY NA WOJNIE: O „BRUDNEJ” UŻYTECZNOŚCI NAUK SPOŁECZNYCH}

Ewa Dżurak

College of Staten Island, The City University of New York

Często przypisywane Ruth Benedict stwierdzenie, że celem antropologii jest „uczynienie świata bezpiecznym dla ludzkiego zróżnicowania” („make the world safe for human differences”), trudno znaleźć, słowo w słowo, w jej pracach. Cytat to jednak chwytliwy, piękny, wieloznaczny i na tyle pojemny znaczeniowo, że od lat wiedzie memowe życie w Internecie w towarzystwie uroczego portretu amerykańskiej antropolożki. Trudno ocenić, czy tę popularność powoduje utopijna wizja pokojowego współistnienia między narodami, czy silna wiara w moc antropologii, której wpływ sięga tak daleko, że ów pokój może zapewnić. Antropologia, nauka, która uczy, jak rozumieć różnorodność kulturową, stoi mocno po stronie tolerancji. Jest zdecydowanie całkowitym przeciwieństwem ksenofobicznej ignorancji. Ignorancję od przemocy dzieli, jak dobrze wiadomo, tylko krótka kładka nad wzburzonym potokiem emocji.

Ruth Benedict miała zapewne na myśli to bezpieczeństwo, które zostało osiagnięte po zwycięstwie $\mathrm{w}$ walce $\mathrm{z}$ faszyzmem, który promował rasizm i szowinizm, gdy wyraziła swoją ideę w przytoczonym wyżej cytacie we wstępie do znanego studium kultury japońskiej (Benedict 1946: 14), opublikowanym tuż po drugiej wojnie światowej. Monografia była efektem pracy Benedict dla Biura Informacji Wojennej rządu Stanów Zjednoczonych podczas drugiej wojny światowej. Projektowi przyświecała oczywista myśl, że lepsze zrozumienie charakteru i zwyczajów egzotycznych Japończyków umożliwi stworzenie materiałów propagandowych, które będą na nich skutecznie oddziaływały, co doprowadzi do szybszego przekonania cesarstwa oraz zakończenia wyniszczającej wojny. 
Analiza i ocena roli cesarza w kulturze japońskiej, dokonana w okresie wojennym przez amerykańskich antropologów, mogła się zapewne przyczynić do postawienia Japończykom warunków kapitulacji możliwych przez nich do zaakceptowania. Świat w istocie stałby się bezpieczniejszy, a siła wiedzy i perswazji antropologów - udowodniona. Głos antropologów nie został jednak wysłuchany, władze amerykańskie zdecydowały, że pewniejsza jest demonstracja siły w postaci bomb atomowych, które zrzucone na Hiroszimę i Nagasaki błyskawicznie skłoniły Japonię do kapitulacji.

Przywołany wyżej cytat z pracy Benedict mógłby stać się mottem do obszernej książki Michała W. Kowalskiego Antropolodzy na wojnie: o „brud-

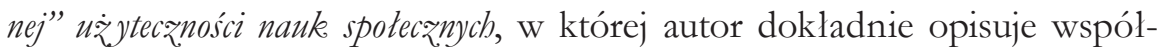
pracę Ruth Benedict z rządem Stanów Zjednoczonych w czasie drugiej wojny światowej. Jest to tylko jeden z epizodów w długiej i złożonej historii związków antropologii i antropologów z wojną i wojskiem oraz ledwie fragment w tej wyczerpującej, skrupulatnej pracy.

Autor jest adiunktem w zakładzie Antropologii Społecznej Instytutu Socjologii Uniwersytetu Warszawskiego i już przed opublikowaniem wspomnianej książki niejednokrotnie pisał na temat zaangażowania antropologów w działania wojenne (m.in. Kowalski 2012, 2013). Były to wprawki do opasłego tomu wydanego przez Wydawnictwa Uniwersytetu Warszawskiego w 2015 roku.

Głównym bodźcem do napisania książki, jak wyznaje autor, było stworzenie współczesnego programu w armii amerykańskiej, zwanego Human Terrain System (HTS), który wdrożono podczas wojny w Afganistanie. Program, z jednej strony, był bezprecedensowy i unikalny, z drugiej, był naturalnym efektem długiej historii współpracy adeptów nauk społecznych z rządem i wojskiem. Realizował przesłanie Benedict w najbardziej bezpośredni i aktywny sposób.

Wprowadzenie kontrowersyjnego HTS w 2006 roku i jego pełne pasji krytyki i oceny wstrząsnęły światem amerykańskich antropologów. Program stał się magicznym lustrem, w którym antropologia ujrzała swoja zniekształcona, „brudna” twarz. HTS sprowokował szereg zaciętych debat i goracych dyskusji na konferencjach naukowych i forach internetowych. Zaowocował licznymi publikacjami na temat etyki w badaniach antropologicznych. Stał się też przyczyną wzrostu zainteresowania tym drażliwym, skrzętnie skrywanym i starannie pomijanym w podręcznikach historii dyscypliny aspektem jej użyteczności - służebnej roli antropologii w konfliktach zbrojnych, w tłumieniu powstań, w aktach podboju. 
W tym nurcie mieści się znakomicie książka Michała W. Kowalskiego, która jest efektem szeroko zakrojonej pracy badawczej nad dziejami zaangażowania nauk społecznych $\mathrm{w}$ działania związane $\mathrm{z}$ wojna: to niezwykle szczegółowa (673 strony), bogata faktograficznie, fascynująca historia antropologii z punktu widzenia jej szczególnego zastosowania, jej przydatności dla urzędników administrujących koloniami, dla generałów planujących działania wojenne, dla organizacji wywiadowczych zbierajacych tajne informacje. Historia wiążąca dzieje antropologii i antropologów, w tym wielu powszechnie znanych luminarzy dyscypliny, takich jak Ruth Benedict, Margaret Mead, Edward Evan Evans-Pritchard, Edmund Leach, Gregory Bateson i wielu, wielu innych, z wojna, z władzami, z wywiadem. Dzieje dyscypliny napisane $z$ tego drażliwego punktu widzenia to wielka rzadkość, w języku polskim pozycja Kowalskiego to unikat. Pisał o tym obszernie między innymi David Price, historyk antropologii zajmujący się jej wojennym zaangażowaniem. Zainteresowanych odsyłam do obszernej bibliografii w książce Kowalskiego. A książka tak wyczerpująca temat, tak szeroko zakrojona, tak bogata w material jest wyjątkową pozycją w historii antropologii w ogóle, ponieważ badacze militarnego zaangażowania antropologii zazwyczaj skupiają się na jednym okresie w historii (zob. także Price 2016).

Tytul: Antropolodzy na wojnie; o „brudnej” użyteczności nauk społecznych jest tylko na pozór oczywisty. Przy każdym bowiem słowie można by postawić znak zapytania. „Antropolodzy” - czyli kto? „Wojna” - czyli co? „Na wojnie” - czyli gdzie? „«Brudna» użyteczność” - czyli jaka? Odpowiedzi na te pytania znajduja się w tekście wraz z licznymi przykładami. Choćby określenie „brudna” pochodzi od terminu „brudna wojna”, używanego przez juntę argentyńską do usprawiedliwienia metod (terroru, tortur, gwałtów), którymi w latach 1976-1983 prowadziła walkę przeciwko lewicowym organizacjom, ich działaczom i w ogóle swoim przeciwnikom. „Brudna” użyteczność w książce Kowalskiego to taka, w której wiedza jest wykorzystywana przeciwko obiektom wcześniejszych badań. Z tytułu mogłoby też wynikać, że autor skoncentruje się tylko na tych najbardziej oczywistych przypadkach, kiedy antropologowie wyruszali na wojnę i czynnie, w terenie, wykorzystywali tę wiedzę na rzecz swego kraju. Tymczasem opisane w książce postawy są bardzo zróżnicowane, reprezentują cała gamę przykładów tego, kim może być antropolog na wojnie.

Kowalski opisuje antropologów-szpiegów, biorących czynny udział w działalności wywiadowczej, antropologów-żołnierzy i partyzantów czynnie służących w armii. Opisuje też działania pomocnicze, na odle- 
głość, w analizowaniu danych i tworzeniu raportów, w stawianiu diagnoz i ekspertyz. Podaje przykłady tajnych wypraw w pojedynkę i oficjalnych, finansowanych przez rządy projektów wykonywanych przez wieloosobowe zespoły badawcze, powołane do formułowania wytycznych dla polityki społecznej.

Książka relacjonuje nie tylko fascynujące wojenne przygody antropologów na frontach różnych kontynentów, lecz także historię stawianych pytań i sporów toczonych o wartości etyczne, jakimi powinny się kierować nauki społeczne, o wartości, jakie powinny obowiązywać badaczy. Pytania o konieczność sformułowania i o rolę kodeksu moralnego badaczy, o ich „brudną” przydatność i tej przydatności usprawiedliwianie. Pytania trudne, niewygodne, nieprzyjemne, wielowarstwowe, których w dzisiejszych czasach nie da się uniknąc i na które nie ma jednoznacznej odpowiedzi.

Książka ma bardzo przejrzysty układ. Składa się z czterech obszernych działów zamkniętych w klamrze wprowadzenia i podsumowania, z których każdy, w chronologicznym porządku, poświęcony jest jednemu okresowi w historii antropologii. Od czasów kolonialnych („Antropolodzy w koloniach”) poprzez wojny światowe („Antropolodzy na frontach drugiej wojny i w okresie «zimnej wojny»”) po współczesność („Antropolodzy na «wojnie z terrorem»"). Działy te sa z kolei podzielone na podrozdziały poświęcone antropologii i antropologom $\mathrm{z}$ różnych tradycji narodowych. Najwięcej miejsca, ze zrozumiałych względów, zajmuje antropologia brytyjska i amerykańska, ale jest też mowa (co rzadkie i bardzo cenne w książce Kowalskiego) o antropologach nazistowskich i japońskich. Mniejsze części podrozdziałów dzielą materiał na konkretne obszary geograficzne, na przykład - „Niemiecki jihad w Afryce - Leo Frobenius”, „Antropolodzy japońscy w koloniach - wyspy Sachalin i Guam”, „Antropolog w służbie imperium - Edward E. Evans-Pritchard" itd.

We wstępie autor zarysowuje problematykę i stawia cztery pytania, na które w dalszej części pracy szuka odpowiedzi. Dlaczego antropologowie angażują się we współpracę z wojskiem? Dlaczego wojsko ich zatrudnia? Jakie są i jakie mogą być w przyszłości konsekwencje tej współpracy dla antropologii jako dyscypliny naukowej? Oraz jakie mogą być społeczne konsekwencje militaryzacji antropologii? Pytania to ogólne, z których wynika cały szereg innych, bardziej szczegółowych. Na ile mocno i blisko antropolog może związać się z władzami, a jednocześnie pozostać wierny swemu kodeksowi etycznemu? Czy antropolog, który jest również obywatelem konkretnego kraju, powinien swoją wiedzą działać na rzecz bezpieczeństwa tego kraju, czy powinien przenieść swoją lojalność tam, gdzie znajduja 
się podmioty jego badania? Czy obywatelski obowiązek antropologów stoi przed ich obowiązkiem naukowym? Na to pytanie amerykańscy uczniowie Franza Boasa odpowiedzieli zupełnie inaczej niż ich bezkompromisowy mistrz i tłumnie zgłosili się do pracy w wywiadzie w czasie drugiej wojny światowej, co szczegółowo dokumentuje Kowalski.

Czy i w jaki sposób zmienią się badania terenowe, główna metoda zbierania danych w antropologii, kiedy antropolog straci zaufanie badanych, bo jego lojalność wobec nich zostanie postawiona pod znakiem zapytania? Czy stosowanie wiedzy antropologicznej w celach wojskowych ma sens praktyczny? Czy antropologia pomogła uniknąć chociaż jednego zamachu terrorystycznego? Jak zmienia to samą dyscyplinę, która tradycyjnie skupia się na małych społecznościach i wykorzystuje metodę badań terenowych - długotrwałego przebywania w terenie, w czasie którego antropolog gromadzi szczegółowe informacje na temat pokrewieństwa, stosunków społecznych, rytuałów, ekonomii? Czy możliwe jest wykorzystanie takiej wiedzy do tworzenia strategii wojskowych? Czy może to przynieść pożądane rezultaty? Jak udowadnia przedstawiona w książce Kowalskiego historia, wiele z tych pytań postawionych w odległych czasach jak bumerang powraca w kolejnych epokach.

Jak piszą Kathleen Gough (1967) i Diane Lewis (1973), antropologia jest dyscypliną zawierająca od samego początku swego istnienia wewnętrzną sprzeczność. Dyscyplina, zrodzona w okresie kolonialnym, która w koloniach się rozwijała, która gromadziła wiedzę za pieniądze władz kolonialnych, którą system kolonialny żywił i której pomagał bujnie rozkwitnąć, boryka się z tym kolonialnym bagażem do dziś. Widać to między innymi w Stanach Zjednoczonych, gdzie w drugiej połowie XX wieku liczba badań wśród Indian amerykańskich, które stanowiły główny motor rozwoju antropologii, zmniejszyła się diametralnie. Nieufność wobec antropologów była tak wielka, poczucie wykorzystywania i zawłaszczenia tak duże, że Indianie po prostu odmawiali współpracy. Czy udział antropologów w działaniach wojennych nie spotka się z jeszcze silniejszą reakcją, tak że może zagrozić wiarygodności całej dyscypliny? Czy są to tylko wewnątrzzawodowe debaty, które dla szerszej publiczności nie mają żadnego znaczenia?

Rozdziały poświęcone antropologii w okresie drugiej wojny światowej, w okresie zimnej wojny i w okresie walki z terroryzmem są niezwykle ciekawe i bardzo wyczerpujące. Autor wyjaśnia i ilustruje złożoność współpracy antropologów z wojskiem, wielopoziomowość tej współpracy, jej wielokierunkowość, problemy etyczne oraz debaty wokół niej się toczące. Na przykład przytacza obszernie płomienne wystapienie Burta Agin- 
sky’ego na zjeździe American Anthropological Association w 1941 roku, tuż po ataku na Pearl Harbor, w którym nawołuje on do zaangażowania się w walkę z tyranią, ponieważ jej zwycięstwo oznaczać będzie koniec nauk społecznych. Aginsky podkreślał, że nie należy mylić „obiektywności z brakiem zaangażowania” (239), i nawoływał do użycia nauk społecznych w walce $z$ nazizmem. Jego postawa, przeciwna całkowicie postawie Franza Boasa, stała się jednak postawą dominującą w czasie drugiej wojny światowej. Być może uwiodło antropologów poczucie własnej misji, poczucie obywatelskiego obowiązku, ale nie bez znaczenia był przecież dostęp do niemal niewyczerpanych funduszy. Antropologia amerykańska nigdy nie miała tyle pieniędzy rządowych, ile w czasie drugiej wojny i tuż po niej, w okresie zimnej wojny. Ogromny, finansowany przez rząd projekt Study of culture at a distance, którego zadaniem było tworzenie profili charakterów narodowych, utrzymujący przez wiele lat ogromny zespół badawczy, zdecydowanie należy już do tamtej epoki. Program tracił stopniowo na znaczeniu, wyschły fundusze, zespół się rozproszył. Antropologowie udali się (tak jak Margaret Mead, szefowa tego programu) na tradycyjne, można by powiedzieć - prawdziwe badania terenowe. Niewiele jednak czasu minęło, kiedy zapotrzebowanie na usługi antropologiczne znowu się pojawiło.

Kowalski szczegółowo opisuje niewiele późniejszą, fascynującą debatę wokół prowadzonych przez Napoleona Chagnona w latach 60. badań wśród Janomamów. Słusznie, bo stanowią najlepszy przykład, kwintesencje problemów, które opisuje Kowalski. Chagnon przedstawił Janomamów jako lud krwiożerczy, dziki, przebywający w stanie permanentnej wojny, sugerując przy tym, że wojna tkwi w naturze człowieka pierwotnego, który agresję ma zakodowaną w genach. Inni antropologowie, poddając krytyce jego tezy, dowodzili, że Chagnon swoją obecnością i rozdawnictwem darów w postaci maczet nie tylko zaburzył panujący wśród Janomamów porządek, lecz także sam przyczynił się do podniesienia poziomu agresji między wioskami rywalizującymi o trudno dostępne dobra. Krytykowano też fakt, że Chagnon przedstawił Janomamów jako lud pozbawiony historii, zastygły w pierwotnym stanie, nietknięty przez zachodzące wokół polityczne, ekonomiczne czy technologiczne zmiany. Okazało się również, że badania te finansowały organizacje wojskowe badające mutacje genetyczne zachodzące pod wpływem broni jądrowej i izolowany lud, taki jak Janomamowie, był znakomita próba porównawczą. Chagnon pobierał próbki krwi bez ujawnienia badanym celu tego zabiegu. Na przykładzie dyskusji wokół jego badań Kowalski pokazuje wyraźnie, czym zgodnie z kodeksem etycznym antropologa badania antropologiczne być nie powinny. Poka- 
zuje też mechanizm przenikania debaty czysto akademickiej do dyskursu publicznego. Problem agresji jako wrodzonego elementu natury ludzkiej dyskutowano szeroko w latach 60. i 70. XX wieku nie tylko z powodu publikacji antropologicznych na ten temat (Morris 1967, 1974, Lorenz 1963, 1972). Wojowniczy Janomamowie opisani przez Chagnona dokładnie się w tę dyskusję wpasowali. Jednak był on najbardziej krytykowany za niejawność swoich badań i za ukrywanie przed podmiotami ich celu. Antropologowie zostali zmuszeni do rewizji etycznych kodów, ich dookreślenia, precyzyjniejszego zdefiniowania, do zajęcia wobec problemów etycznych jasnego stanowiska. Debata nad rezultatami badań Chagnona stanowiła moment zwrotny w spojrzeniu na przydatność antropologii i etykę antropologa, a zbiegła się w czasie z ogłoszeniem walki z terroryzmem. Szybko powstał kolejny program angażujący antropologię w wojnę, wspomniany HTS, który zakładał między innymi, że antropolog w mundurze i w pełnym ekwipunku razem ze swą drużyną wyruszy na misję w terenie.

Najwięcej wątpliwości budzi rozdział pierwszy poświęcony antropologii kolonialnej. Główną tego przyczyną jest przyjęcie przez autora niezwykle szerokiej definicji antropologa. Czy możemy uznać za antropologa każdego, kto interesował się zwyczajami, zbierał artefakty czy uczył się języka innego ludu? Jest to niewatpliwie kwestia umowna. W okresie formatywnym antropologii badaczami kultur tubylczych byli przede wszystkim amatorzy, pasjonaci, przyrodoznawcy, lingwiści, którzy ludy tubylcze traktowali jak egzotyczną ciekawostkę, jak część przyrody, jak element badanego środowiska. Jeżeli Kowalski mówi, że ktoś był wyszkolonym antropologiem w Stanach Zjednoczonych przed rokiem 1896 (kiedy Boas założył pierwszy wydział antropologiczny na Columbia University), to kogo ma na myśli? Autor mówi o Johnie Wesleyu Powellu, geologu i odkrywcy Amerykańskiego Zachodu, założycielu i pierwszym dyrektorze Bureau of Ethnology w Smithsonian Institution. Ale dlaczego nie wspomina o Lewisie Morganie, autorze Ligi Irokeskiej, którego śladami kroczył Powell? Warto zaznaczyć, że antropologia ma wielu ojców, wujów, niezliczone ciotki i całe grono ubogich krewnych. Nie ujmując zasług tej wielkiej rodzinie, wydaje się, że węższa definicja przysłużyłaby się przejrzystości pierwszej części książki.

Wydaje się też, że byłoby niezwykle interesujące, gdyby autor zaproponował typologie postaw antropologów wobec problemu wojny i ich użyteczności dla wojska. W książce przedstawia całe spektrum - od postaw ludzi luźno związanych z antropologia, takich, którzy przy okazji obserwują zwyczaje innych, po posiadaczy antropologicznych stopni naukowych, których wcielono do plutonów patrolujących wioski afgańskie. Czy oficerowie 
brytyjscy, którzy badali zwyczaje ludów afrykańskich czy azjatyckich, powinni stać w tym samym szeregu co archeolodzy amerykańscy w Ameryce Łacińskiej w czasie pierwszej wojny światowej, traktujący swoje wyprawy wykopaliskowe jako korzystne alibi do szpiegowania przeciwko państwom Osi? Czy Evans-Pritchardowi, który na ochotnika zgłosił się do armii i organizował partyzantkę wśród Anuaków w Etiopii, bliżej do antropologów wcielonych do oddziałów w ramach HTS czy do innych oficerów brytyjskich świadomych faktu, że wiedza o kulturze przydaje się do tłumienia punktów oporu w koloniach? Ta właśnie różnorodność jest z jednej strony fascynująca i barwna, ale z drugiej trudna do objęcia i aż woła o ściślejsze definicje - o typologię metod i sposobów zaangażowania w działalność na rzecz wojska i ocenę ich ewentualnej skuteczności.

Debaty z ostatniego dziesięciolecia, debaty wokół HTS, postawiły sprawę zaangażowania antropologów w wojnę w bardzo ostrym świetle. Jednak nawet to najbardziej bezpośrednie zaangażowanie się w działania wojenne, przywdzianie mundurów i udział w patrolach, działania potępione w oficjalnym oświadczeniu AAA, które spowodowały powstanie niezależnych zrzeszeń antropologów zwalczających ideę HTS (na przykład Network of Concerned Anthropologists - NCA), mają ciągle wielu zagorzałych zwolenników, uzasadnieniom których nie można odmówić sensu. Zadaniem antropologów-żołnierzy jest mediowanie w sprawach wioskowych, tłumaczenie, wyjaśnianie lokalnych stosunków władzy, łagodzenie konfliktów z żołnierzami. Poza tym patrolowanie to tylko fragment HTS. Duża część programu, o czym nie można zapominać, polegała na przygotowywaniu materiałów szkoleniowych dla żołnierzy, tłumaczeniu stosunków rodzinnych, objaśnianiu znaczenia gestów i obowiązującej etykiety, słowem - była nauką różnic kulturowych. Skuteczność działania programu pozostaje do ocenienia. Czy w praktyce antropolog patrolujący w mundurze może być kimś więcej niż tłumaczem? To i wiele innych pytań czeka na odpowiedź w przyszłości. Program HTS został zarzucony przez armię amerykańską w 2014 roku wraz z wycofaniem się głównych sił amerykańskich z Afganistanu. Czy to oznacza, że antropologia militarna była epizodem? Czy flirt z władzami, z wojskiem powtórzy się przy kolejnej sprzyjającej okazji, tak jak to było już i po pierwszej, i po drugiej wojnie światowej?

Historia jest zawsze ciekawa, ale najciekawsze jest to, co z niej wynika, jaka płynie z niej nauka, czego się wystrzegać i co przemyśleć od nowa. Kowalski bardzo dobrze przedstawia historię dyskusji na temat etyki zawodowej antropologa, na temat zasad, jakimi powinien kierować się badacz terenowy w czasach, kiedy antropologia stosowana jest faktem. Przydatno- 
ści antropologii stosowanej - rozumianej jako użyteczność danych antropologicznych, antropologicznej perspektywy czy etnograficznych metod do wyodrębnienia, zauważenia, oceny czy podejmowania prób rozwiązania problemów społecznych - nie da się zanegować. W medycynie, biznesie, badaniach na rzecz środowiska antropolodzy pracują dla organizacji, które próbuja rozwiązywać skomplikowane problemy społeczne. Jednak działania na rzecz wojska to zupełnie inna sfera, stawiająca te same problemy etyczne w jakby innej skali: w jaskrawym świetle eksplozji, wśród ruin domów, w wymiarze silnych emocji, w głębszej i szerszej perspektywie praw człowieka. Wiele pytań pozostaje bez jednoznacznej odpowiedzi. Na przykład pytanie, czy antropologia może być skutecznie zastosowana, gdy zostanie pozbawiona bazy długotrwałych badań terenowych i zostanie zmuszona do produkowania bieżących ekspertyz? Autor interesująco oddaje uwikłanie dyscypliny w rzeczywistość - nauka nie istnieje sama dla siebie, zwłaszcza nauka społeczna, ale zawsze jest na służbie swoich czasów.

Bibliografia:

/// Benedict R. 2016. Chryzantema i miecz, tłum. E. Klekot, Państwowy Instytut Wydawniczy.

/// Gough K. 1967. Anthropology and Imperialism, referat wygłoszony na konferencji South-Western States Anthropological Association Meetings, San Francisco, California.

/// Kowalski M.W. 2012. Antropologia na wojnie. Historia i teraźniejszość udziatu antropologów w konfliktach wojennych, „Zeszyty Naukowe WSOWL”, nr 1(163), s. 119-132.

/// Kowalski M.W. 2013. Antropolodæy na wojnie: o „brudnej” u之̇yteczności nauk społecznych, Przegląd Socjologii Jakościowej, t. 9, nr 3, s. 124-141.

/// Lewis D. 1973. Anthropology and colonialism, "Current Anthropology”, nr 14(5), s. 581-602.

/// Lorenz K. 1972. Tak zwane żło, tłum. A.D. „Tauszyńska, Państwowy Instytut Wydawniczy.

/// Morris D. 1974. Naga małpa, tłum. J. Prokopiuk, T. Bielicki, J. Koniarek, Wiedza Powszechna.

/// Price D.H. 2016. Cold War Anthropology: The CIA, The Pentagon and the Growth of Dual Use Anthropology, Duke University Press. 